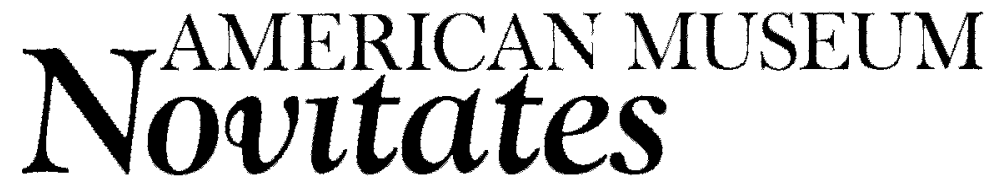

PUBLISHED BY THE AMERICAN MUSEUM OF NATURAL HISTORY CENTRAL PARK WEST AT 79TH STREET, NEW YORK, NY 10024 Number 3523, 18 pp., 7 figures, 1 table

\title{
Extralimital Fossils of the "Gondwanan" Family Sphaeropsocidae (Insecta: Psocodea)
}

\author{
DAVID GRIMALDI ${ }^{1}$ AND MICHAEL S. ENGEL ${ }^{2}$
}

\begin{abstract}
Two new species and genera of minute, coleopteriform psocopterans, family Sphaeropsocidae (Nanopsocetae), are described from fossils preserved in Cretaceous ambers: Sphaeropsocoides canadensis Grimaldi and Engel, n.gen., n.sp., from the Campanian of western Canada; and Sphaeropsocites lebanensis Grimaldi and Engel, n.gen., n.sp., from the Neocomian of Lebanon. These are the first described Mesozoic species of the family. Sphaeropsocus kuenowii Hagen in midEocene Baltic amber is redescribed in detail. The 14 described Recent species of the family (in the genera Sphaeropsocopsis and Badonnelia) have natural distributions that are largely restricted to southern portions of the Southern Hemisphere, but Eocene and now Cretaceous fossils reveal a formerly global distribution of the family. Hypothesized relationships of the five genera indicate basal positions of the fossil genera, and probably an entirely Tertiary age of the Recent genera Sphaeropsocopsis and Badonnelia, which would thus be too young for these two genera to have been affected by gondwanan drift.
\end{abstract}

\section{INTRODUCTION}

Breeding amidst the humus of southern temperate forests are minute, beetlelike insects with elytriform forewings, which are the Sphaeropsocidae, coelacanths of the Psocoptera. Like coelacanths, these were first known as fossils, but in this case exquisitely preserved in mid-Eocene Baltic amber (Hagen, 1882: fig. 1). Living relatives were not discovered until the early 1930s (again like coelacanths), some 50 years later, based on a species from Tasmania (Hickman, 1934). That Tasmanian species, Sphaeropsocus recens Hickman, was later transferred to a new but obviously closely related genus, Sphaeropsocopsis, along with four Recent species from Chile, Argentina, and Ascension Is-

\footnotetext{
${ }^{1}$ Division of Invertebrate Zoology, American Museum of Natural History (grimaldi@amnh.org).

${ }^{2}$ Division of Invertebrate Zoology, American Museum of Natural History; Division of Entomology (Paleoentomology), Natural History Museum, and Department of Ecology and Evolutionary Biology, Snow Hall, 1460 Jayhawk Boulevard, University of Kansas, Lawrence, Kansas 66045-7523 (msengel@ku.edu).
} 

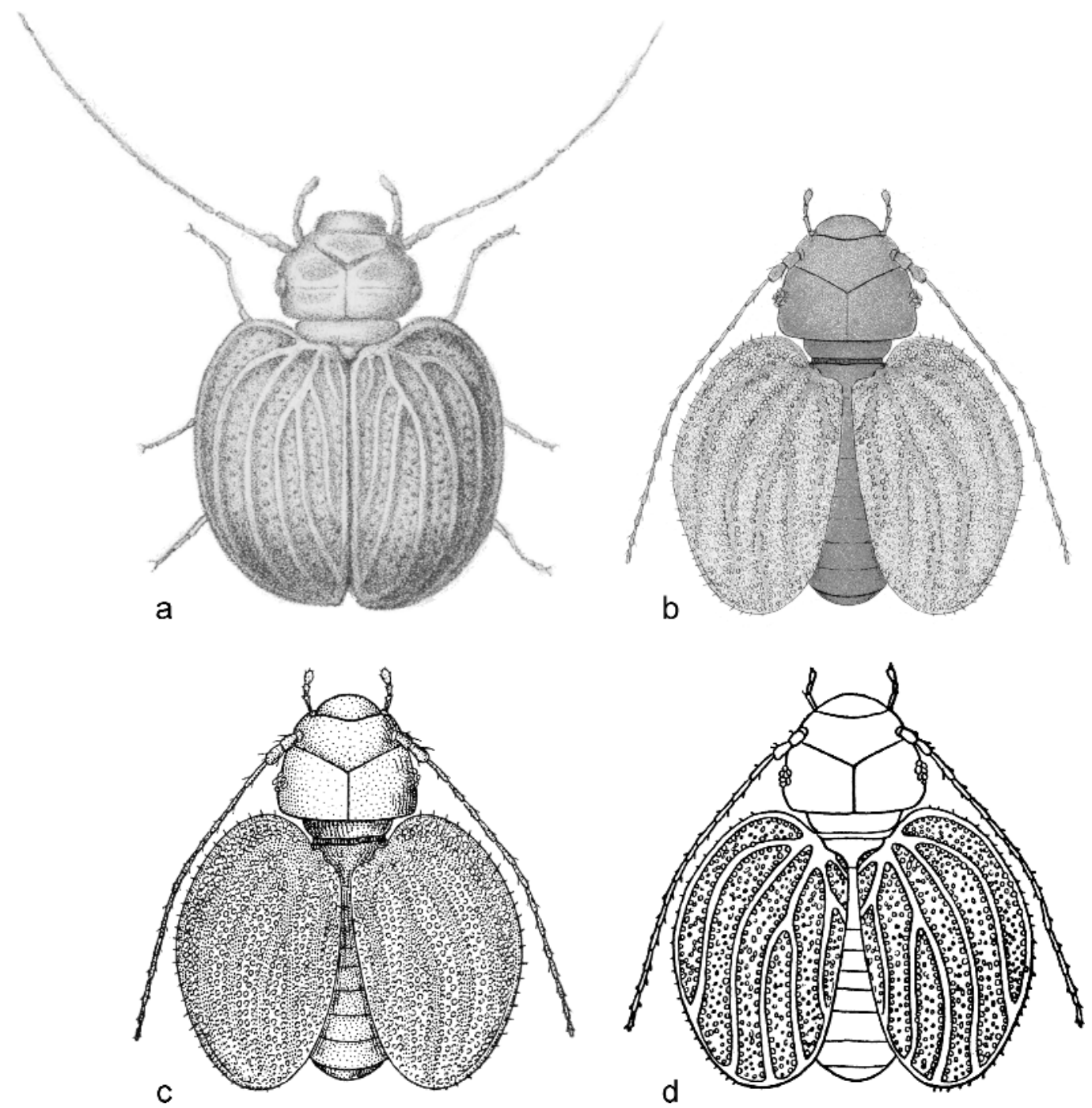

Fig. 1. Sphaeropsocus kuenowii Hagen (slightly reconstructed), as originally illustrated by Hagen, 1882 (a), by Enderlein, 1911 (b), by Badonnel, 1951 (c), and by Bekker-Migdisova and Vishniakova, 1962 (d). All authors erroneously depicted this species with a fully developed, Y-shaped frontal "suture" (which is actually an ecdysial cleavage furrow or scar; since true sutures represent segmental lines). In fact, note how later authors had simply redrawn Enderlein's illustration. Interestingly, Hagen (1882) was far more accurate than his successors in the description and depiction of this species, the latter of whom erroneously depicted a forked cubital, a long stem of vein $\mathrm{M}$, and the anterior margin of the forewing as barely cordate. Despite improvements in optics, the iconography of this interesting species suffered from a steady decline in original and critical observations.

land (Badonnel, 1962, 1963). Since that time four additional Recent Sphaeropsocopsis species have been discovered from Chile, Angola, and St. Helena Island in the southern Atlantic (Badonnel, 1967, 1971, 1972; Camousseight and New, 1994; Lienhard and
Ashmole, 2000). The closely related Recent genus Badonnelia contains four species from Chile (Badonnel, 1963, 1967, 1972; Camousseight and New, 1994) and one species is widespread throughout Europe, $B$. tite $i$ Pearman (reviewed in Lienhard and Smi- 
thers, 2002). With the possible exception of a putative but as yet undescribed Sphaeropsocopsis from California (Mockford, 1993) and $B$. titei, both of which are plausibly introduced, the Recent Sphaeropsocidae are essentially or even entirely a gondwanan group. Yet the Baltic amber species indicates these insects roamed far into the Northern Hemisphere during at least the Eocene.

Here we further document the former global spread of Sphaeropsocidae by describing the first Cretaceous species, from the Early Cretaceous of Lebanon and Late Cretaceous of western Canada. This is an appropriate opportunity to also redescribe Sphaeropsocus kuenowii Hagen, based on detailed examination of the type and of new material, and to consider relationships of the five genera.

\section{MATERIALS AND METHODS}

Some amber pieces were prepared according to the protocols described by Nascimbene and Silverstein (2000), particularly the more fractured and brittle Cretaceous pieces. This involved preliminary trimming and grinding, then embedding the pieces in a very durable epoxy, and finally trimming, grinding, and polishing (often within less than one millimeter of the inclusion) so that the inclusion could be studied with compound microscopy at 100 $400 \times$. The Lebanese amber specimen in this study was collected in the 1970s by Aftim and Fadi Acra from near Jezzine and dates to approximately 120-125 Ma (Azar, 2000). The Canadian amber specimen was collected by J.F. McAlpine and J.E.H. Martin (1969) in the 1960s from near Cedar Lake, Manitoba, in outcrops of the Campanian-aged Foremost Formation (ca. 75-80 Ma). Baltic amber derives from vast deposits of the blaue Erde in northern Europe, which is mid-Eocene in age, ca. $45 \mathrm{Ma}$ (Kosmowska-Ceranowicz, 1987; Ritzkowski, 1997).

Institutions that are repositories for the material examined are the following:

AMNH American Museum of Natural History, New York, Division of Invertebrate Zoology (Acra Collection of Lebanese amber)

CNC Canadian National Collection of Insects and Spiders, Agriculture
Canada, Ottawa, Ontario; courtesy of Dr. Jeff Cumming.

MCZ Museum of Comparative Zoology, Department of Entomology, Harvard University, Cambridge MA; courtesy of Dr. Phil Perkins.

NHM Natural History Museum, London, Department of Palaeontology; courtesy of Dr. Andrew J. Ross.

KU Snow Entomological Collection, Division of Entomology, University of Kansas Natural History Museum, Lawrence.

The following abbreviations are used herein for the various genera in the family so as to avoid confusion when discussing them together in condensed form: Sphaeropsocus (S.), Sphaeropsocopsis (Sp.), Sphaeropsocoides $(S d$.), and Sphaeropsocites (Si.).

\section{SYSTEMATICS}

\section{FAMILY SPHAEROPSOCIDAE KOLBE}

Sphaeropsocini Kolbe, 1883: 190. Type genus: Sphaeropsocus Hagen, 1882. Handlirsch, 1907: 702 [elevated to familial rank]; Menon, 1942: 24; Pearman, 1958: 52; Bekker-Migdisova and Vishniakova, 1962: 230; Mockford, 1993: 63.

Diagnosis: Minute, prognathous psocopterans (ca. $1.0 \mathrm{~mm}$ in body length); forewings of female elytriform (male micropterous), with reduced venation and fine to coarse punctation or areolation; hind wings absent; coxae closely situated; compound eyes with $0-10$ ommatidia; ocelli absent.

INCLUDED GeNERA: Sphaeropsocopsis Badonnel (nine Recent species: Chile, Angola, Tasmania, St. Helena Is.), Badonnelia Pearman (five Recent species: Chile, Europe), Sphaeropsocus Hagen (Baltic amber), Sphaeropsocites n.gen. (Lebanese amber), and Sphaeropsocoides n.gen. (Canadian amber). Another fossil, perhaps the fourth fossil species, is preserved in amber from the Late Cenomanian-aged Dolganian Formation (ca. 93-94 Ma) of the Taimyr Peninsula, Siberia (Rasnitsyn and Quicke, 2002: fig. 164), currently being studied elsewhere.

Comments: Most psocopteran systematists attribute the family name to Menon (1942), but it was actually validated much earlier by Kolbe (1883) as a tribe and sub- 


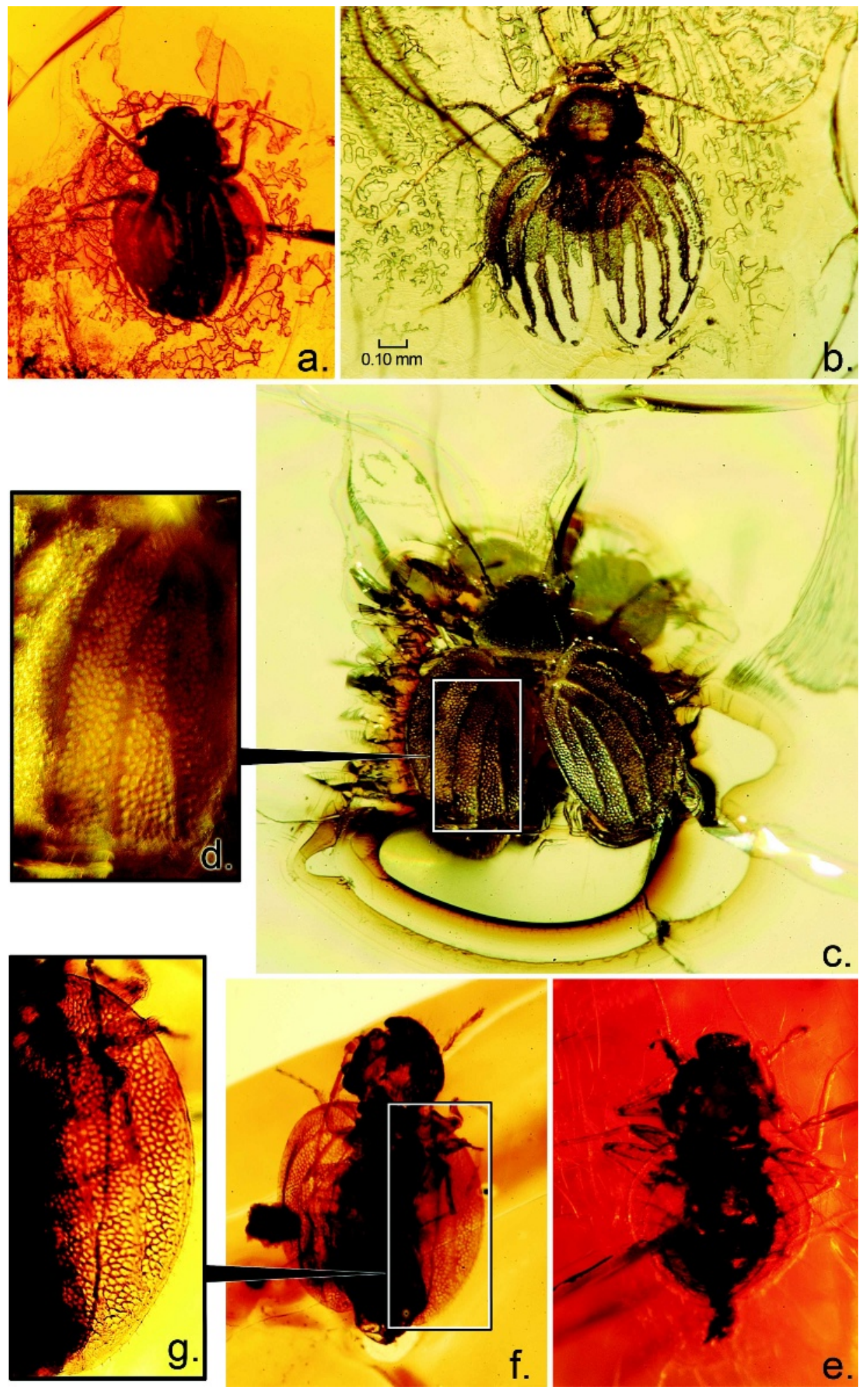


sequently applied by Handlirsch (1907) as a family. The family belongs to the Nanopsocetae, ${ }^{3}$ which is presently known to consist of a monophyletic lineage that also contains the Pachytroctidae, the Liposcelididae, and the lice (order Phthiraptera ${ }^{4}$ ). This grouping is based on morphology (Pearman, 1936) and DNA sequences (Johnson et al., 2004). Pachytroctidae is a family of 10 genera and approximately 90 described species, whose natural distribution is circumtropical and warm temperate. Liposcelididae is a family of one extinct and nine Recent genera with 181 described species, most of which are in the familiar genus of "book lice," Liposcelis. The most interesting aspect of the Liposcelididae is that they are the sister group to the true, ectoparasitic lice (Lyal, 1985; Yoshizawa and Johnson, 2003). The fossil record of lice is virtually nonexistent, but like the Sphaeropsocidae all the fossils of Liposcelididae are preserved in amber. A recent study of fossil Liposcelididae indicates an origin of the family and probable divergence from the lice in the Early Cretaceous or possibly latest Jurassic (Grimaldi and Engel, 2005b), which is an age that corresponds well with the fossil record of Sphaeropsocidae that we report here.

\section{Genus Sphaeropsocus Hagen}

Sphaeropsocus Hagen, 1882: 226. Type species: Sphaeropsocus kuenowii Hagen, 1882, by monotypy.

Palaeotroctes Enderlein, 1911: 350. Type species: Atropos succinica Hagen, 1882, by monotypy. Synonymy vide Pearman, 1958: 51.

Diagnosis: (modified from Badonnel, 1963; Smithers, 1972; Mockford, 1993). Disting-

Fig. 2. Photomicrographs of fossil Sphaeropsocidae. a-d. Sphaeropsocus kuenowii Hagen in mid-Eocene Baltic amber. a. Holotype, MCZ 235. b. KU B-144. c, d. KU B-148, showing detail of the areolate, elytrous forewings. e. Sphaeropsocites lebanensis Grimaldi and Engel, n.gen., n.sp., holotype, AMNH JS-284. f, g. Sphaeropsocoides canadensis Grimaldi and Engel, n.gen., n.sp., holotype CNC 642. All photos except "d" to the same scale. uished from Badonnelia on the basis of less reduced venation of the female forewings (vide Badonnelia, infra); distinguished from Sphaeropsocopsis by not having the apices of $\mathrm{Rs}, \mathrm{M}$, or $\mathrm{Cu}$ fused; from Sphaeropsocites by having $\mathrm{P}_{4}$ not swollen, eyes distant from posterior margin of head, $\mathrm{M}$ and Rs not fused, and no crossveins; from Sphaeropsocoides by having very short to virtually no stems for $\mathrm{R}, \mathrm{M}$, and $\mathrm{Cu}$, and tibiae without apical spurs.

\section{Sphaeropsocus kuenowii Hagen \\ Figures 1, 2a-d, 3, 4}

Sphaeropsocus künowii Hagen, 1882: 226. In Baltic amber. Name emended to kuenowii in accordance with ICZN (1999: Art. 32.5.2.1).

Atropos succinica Hagen, 1882: 231. Synonymy vide Pearman, 1958: 51

Troctes succinicus (Hagen); Kolbe, 1883: 190.

Palaeotroctes succinicus (Hagen); Enderlein, 1911: 350

Sphaeropsocus künowi Enderlein, 1911: 352. Lapsus calami pro Sphaeropsocus kuenowii Hagen, 1882.

Diagnosis: As for genus (vide supra).

DESCRIPTION: (Female) (measurements based on KU B-144): Minute psocopteran, body length sans forewings ca. $0.60 \mathrm{~mm}$, with forewings $1.0 \mathrm{~mm}$. Head: Prognathous; broad, width $0.8 \times$ the length. Anterior tentorial pits short, sulcuslike, convergent just above clypeus; tentorium well-developed, with tentorial bridge and anterior tentorial arms; median "coronal suture" extended from posterior margin of head to level of eyes. Ocelli absent. Compound eyes small, with seven facets not contacting each other. Clypeus of modest

\footnotetext{
${ }^{3}$ The name Nanopsocetae was first established by Pearman (1936) and not by Broadhead (1950) as widely cited by many authorities.

${ }^{4}$ The difficulty of paraphyly of Psocoptera, Troctomorpha, and Nanopsocetae with respect to the true lice could be easily obviated by the demotion of Phthiraptera to a category within the infraorder Nanopsocetae and the reduction of its constituent suborders to more subordinate categories. The family-group classification of the lice would be entirely unaffected. This would certainly be preferable to the splitting of Psocoptera into innumerable new orders, would minimize the number of taxonomic changes (only five changes), and would permit the reflection of hierarchical relationships in the classification of "higher" Psocodea. Such a classification should be seriously considered by louse systematists.
} 


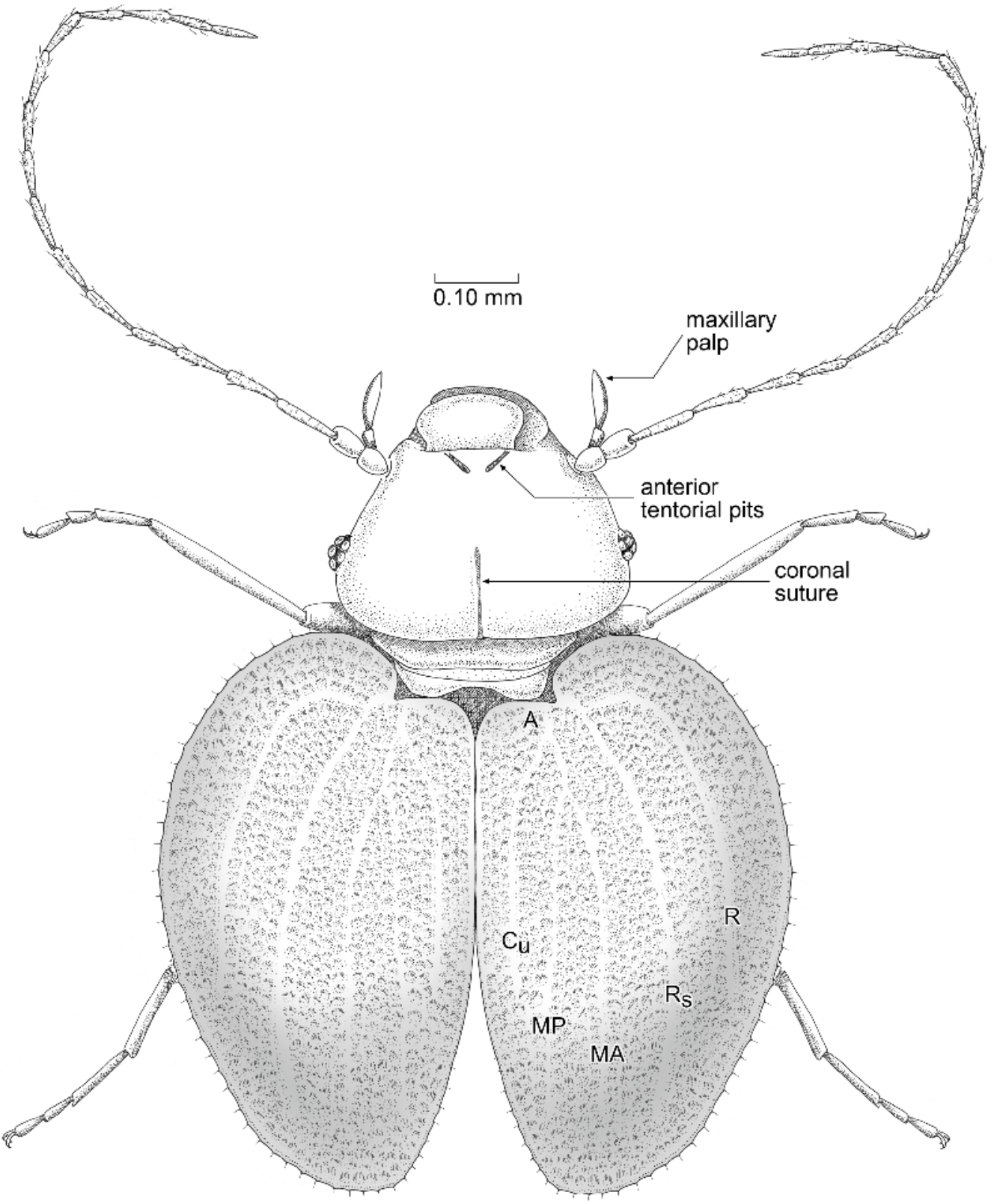

Fig. 3. Dorsal habitus of Sphaeropsoscus kuenowii Hagen (KU B-144), in mid-Eocene Baltic amber, slightly reconstructed.

size; mandibles large; labial palps highly reduced (pair of small 1-segmented polyps on anterior margin of labium), area between labium and occipital foramen membranous. Maxillary palps 4-segmented, lengths of segments (longest to shortest): P4-2-3-1. Apical palpomere $\left(\mathrm{P}_{4}\right)$ spindle-shaped, apical half with oval sensillar area on ventral surface. Right lacinia protrudent, apex with one small and two large teeth. Antenna length $10.5 \mathrm{~mm}$; scape and pedicel twice width of flagellomeres, approximately half the length of basal flagellomere. Flagellum with 13-14 articles, each flagellomere with 

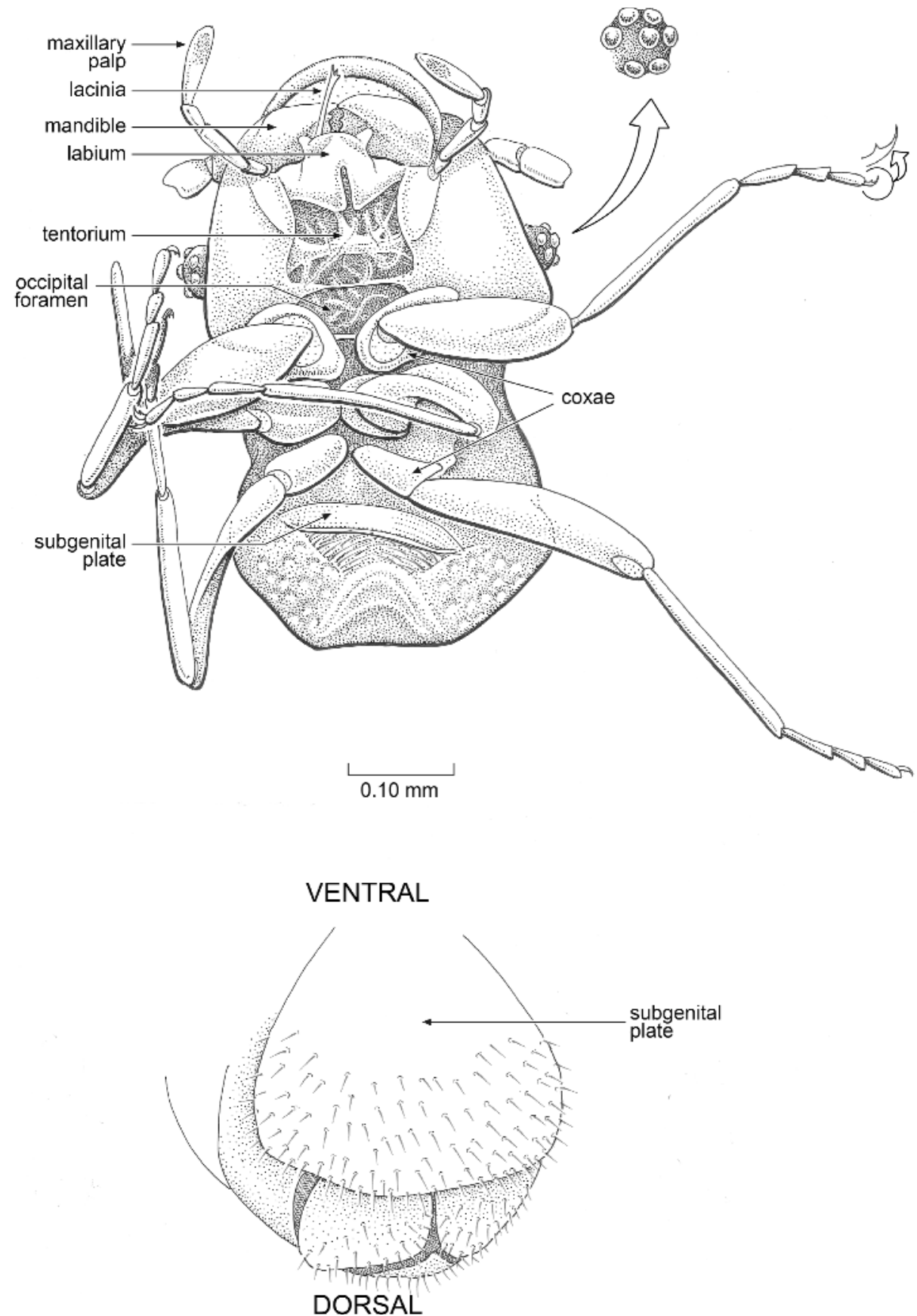

Fig. 4. Ventral habitus of Sphaeropsocus kuenowii Hagen (KU B-148), with detail of compound eye and terminal sternites. 
fine annuli, and all but basal flagellomere with sparse setulae.

Thorax: Short, dorsally with only pronotum and mesoscutum exposed. Legs of moderate length, ca. $0.60-0.65 \mathrm{~mm}$. Coxae large, opposites of each pair nearly touching medially; procoxae larger than metathoracic pair. Femora thick, width of profemur $3.5 \times$ width of protibia, of metafemur $2.7 \times$ width of metatibia; profemoral length $0.18 \mathrm{~mm}$; metafemoral length $0.25 \mathrm{~mm}$. All tibiae approximately equal in length $(0.20 \mathrm{~mm})$ and width; no apical spurs present. Tarsi trimerous, total length $0.13 \mathrm{~mm}$; basal tarsomere slightly longer than others; pretarsal claw with preapical tooth. Wings: Forewings present only (hind wings absent); forewing elytrous, carapacelike, length $0.67 \mathrm{~mm}$, greatest width $0.38 \mathrm{~mm}$; anterior margin cordate. Surface of wing between veins areolate, with dense, irregular depressions. Venation highly reduced, consisting of: circumambient $\mathrm{C}, \mathrm{R}$ and Rs, MA and $\mathrm{MP}, \mathrm{Cu}$, and very short $\mathrm{A}$ (for proportions see fig. 3). Stem of $R$ and $M$ very short, but length variable even between wings of same specimen. Surface of veins minutely papillate, devoid of areolae. Apices of veins not reaching margin of wings. Outer margin of wing with row of minute, stiff setulae. Wings meet in straight line for approximately half their mesal length; divergent mesally in apical half.

Abdomen: Short, globose, approximately same size as head, dorsally obscured by forewings, ventrally exposing little or very obscure segmentation. Apical half of abdomen ventrally covered with large subgenital plate; plate with posterior margin entire (not bilobed or emarginate). In KU B-144 subgenital plate lifted, exposing what appears to be two opposing brushes of fine setulae and pocked surface of cuticle.

Holotype: MCZ 235 (fig. 2a), "no. 103" in handwriting [presumably Hagen's]. Specimen was preserved in a square chip of amber that was heavily crazed and darkened to a very deep red from years of exposure (it was originally mounted between a piece of folded paper that was then pinned, and may have originally been stored in a pinned collection). The piece was embedded in epoxy at the AMNH and ground and polished in order to expose fresh surface for viewing critical details.
Additional Material Examined: KU B$144,-148,-154$, all of which are preserved in middle Eocene Baltic amber from Germany, as well as a specimen preserved in Late Eocene amber from the Rovno region of the Ukraine (Engel and Perkovsky, 2006a, 2006b).

Comments: This species has been referred to frequently in literature on insect fossils, and illustrations of it often reproduced and refigured (e.g., Badonnel, 1951; Carpenter, 1992) (fig. 1). Despite this, and the fact it is not particularly rare in Baltic amber, this intriguing species has never been redescribed in detail. We have found that Hagen's original illustration (fig. 1a) and description are remarkably accurate, which we can modify only slightly. The short vein A of the forewing is not present in the type specimen, and in other specimens A branches off at the very base of the stem of $\mathrm{M}+\mathrm{Cu}$, not off of $\mathrm{Cu}$ as depicted by other authors. Also, the longitudinal veins are incomplete and do not reach the wing margin.

\section{Genus Sphaeropsocopsis Badonnel}

Sphaeropsocopsis Badonnel, 1963: 322. Type species: Sphaeropsocopsis chilensis Badonnel, 1963, by original designation.

Diagnosis: Modified from Badonnel (1967, 1971, 1972), Smithers (1972), and Mockford (1993): (Female) Forewings with 4-5 main longitudinal veins (generally missing $\mathrm{MP}$ ), apices of at least $\mathrm{Rs}, \mathrm{M}$, and $\mathrm{Cu}$ fused distally (but distant from wing margin); wing membrane finely and densely areolate; maxillary palpomere $4\left(\mathrm{P}_{4}\right)$ fusiform; female terminalia with V3 deeply lobed.

INCLUDED SPECIES: There are nine described species in the genus, all of them Recent. Five of the species are known only from Chile: Sp. chilensis Badonnel, 1963; Sp. microps Badonnel, 1963 (specimens "cf. microps" are also reported from Ascension Island in the mid-Atlantic); Sp. spinosa Badonnel, 1972; Sp. valdiviensis Badonnel, 1972; and Sp. valeriae Badonnel, 1967. Sphaeropsocopsis argentina (Badonnel, 1962) occurs in Argentina (but has also been introduced into the United States; see Relationships and Biogeography, below); $S p$. recens occurs in Tasmania and southeastern Australia (Hickman, 1934); Sp. riesi 
Badonnel, 1972 occurs in Angola; and there is a blind cave species on St. Helena Island ( $S p$. myrtleae Lienhard and Ashmole, 1999). Sphaeropscopsis myrtleae was placed into this genus only on the basis of undivided mesothoracic sternites and eye reduction; the brachypterous forewings are so reduced as to obscure whether they possessed the characteristic venation and areolae.

Mockford (1993) mentioned a possible Sphaeropsocus from California, known only from three $q$ specimens representing possibly two species, but which may be a Sphaeropsocopsis. According to Mockford (1993: pg. 64) these specimens have six veins "including $\mathrm{Cu}_{2}$, but $\mathrm{Cu}_{1}$ is simple and joins $\mathrm{M}_{2}$ distally" (this last feature diagnostic of Sphaeropsocopsis). Given that one species from Argentina, Sp. argentina (Badonnel, 1962), has been introduced into the United States, it is quite possible that the California specimens were also from an introduced population.

\section{Genus Badonnelia Pearman}

Badonnelia Pearman, 1953: 262. Type species: Badonnelia titei Pearman, 1953, by original designation.

Diagnosis: Distinguished from Sphaeropsocopsis entirely on the basis of apomorphic features: Forewings also elytrous but bent down at sides of abdomen, with only two main veins and "hexagonal pattern of ridges." Compound eye with seven ommatidia (vs. "variable"). Cuticle of body with fine granular microsculpture. Fourth maxillary palpal segment $\left(\mathrm{P}_{4}\right)$ subcylindrical, elongate (vs. "fusiform").

InCLUDED SPECIES: There are five described species, the first four of which are from Chile: $B$. castrii Badonnel, 1963; B. granulosa Badonnel, 1972; B. similis Badonnel, 1963; B. testacea Badonnel, 1972; and B. titei. Badonnelia titei is widespread throughout western Europe, from the UK to Finland and Sweden, and to Switzerland, but probably introduced to that area.

Comments: As diagnosed this genus would appear to render Sphaeropscopsis paraphyletic, since it is defined entirely on the basis of characters that are apomorphic with respect to these genera. Before any formal synonymy of genera is proposed it would be important to examine the detailed morphology of as many
Recent species of sphaeropsocids as possible. Such a study should also determine the exact relationship of $B$. titei to the other (austral) species of the genus, although based on published descriptions it appears to be typical of other species in the genus.

It must be seriously considered that $B$. titei is a species as yet unknown from Chile or which is a senior synonym of one of the four species described by Badonnel, but which was introduced to western Europe. Thus far, the species is known from Belgium, Finland, Great Britain, Ireland, Luxembourg, Norway, Sweden, and Switzerland. A EuropeChile disjunction is an extremely unusual distribution for any group of organisms, particularly for a group that we hypothesize as very young and derived from a naturally austral group (Sphaeropsocopsis). Most significant is that published anecdotes reveal the "librophilous" nature of $B$. titei and how it is easily spread by humans. O'Connor (1987), for example, documented how $B$. tite $i$ was received in a shipment of books to Scotland, and even the type specimen of the species was found in the binding of an old atlas in the museum at Tring, England (Pearman, 1953)! (Full citation of the "type locality" was not specified, but apparently it was not the page with a map of Chile). We believe that Badonnelia is probably naturally endemic to Chile.

\section{Sphaeropsocoides Grimaldi and Engel,} new genus

TyPe SPecies: Sphaeropsocoides canadensis, new species, in Cretaceous Canadian amber.

DiAGNOSIS: Anterior margin of forewing slightly less cordate than in Recent genera. Venation most similar to that of Sphaeropsocus, with five main veins, their apices not meeting wing margin (but closer to margin in Sphaeropscoides) nor apically fused; and with stem of $\mathrm{R}$, stem of $\mathrm{M}$, and $\mathrm{Cu}$ slightly longer. Antennal flagellum with 12 segments (vs. 1314); tibia with two apical spurs; pretarsal claw with small preapical tooth.

ETYMOLOGY: Base of the name is from the type genus of the family, and the suffix -oides from the Greek -eides or -eidos, meaning "like" or "having the form of". 
Sphaeropsocoides canadensis Grimaldi and Engel, new species

Figures $2 \mathrm{f}-\mathrm{g}, 5$

Diagnosis: As for genus (see above).

Description: (Female) (measurements based on holotype, CNC 642): Minute psocopteran, body length with forewings $0.97 \mathrm{~mm}$. Body somewhat compressed, so proportions are probably slightly distorted. Head: Prognathous; broad, width approximately equal to length. Anterior tentorial pits unapparent; pair of long, fine setae on anterior margin of head; median "coronal suture" extended from posterior margin of head to level of anterior margin of eyes. Ocelli absent. Compound eyes small, with approximately six facets not contacting each other [difficult to discern]. Clypeus of modest size; labial palpi visible in $\mathrm{CNC}$ 644, a pair of small lobes on anterior margin of labium [paraglossae?]; fine, stiff setae on margins, with 1 thick seta at apex of palp having slightly bifid apex. Maxillary palp 4-segmented, lengths of palpomeres (longest to shortest): P4-2-3-1. Apical palpomere $\left(\mathrm{P}_{4}\right)$ narrow ovoid to spindle-shaped, apical half with dark area, presumably sensillar area. Palpomeres $\mathrm{P}_{2}$ and $\mathrm{P}_{3}$ each with lateral patch of dense microtrichia (presumably sensilla). Lacinia protrudent, length equal to that of $\mathrm{P}_{4}$, apex with one small and two large teeth. Antenna length $8.1 \mathrm{~mm}$; scape and pedicel twice width of flagellomeres, slightly longer than half the length of basal flagellomere. Flagellum with 12 articles, each flagellomere with fine annuli.

Thorax: Short, dorsally with only pronotum and mesoscutum exposed. [Leg lengths and other proportions difficult to discern], ca. $0.60-0.65 \mathrm{~mm}$. Tibiae with pair of small apical spurs, length of spurs approximately equal to width of tibia. Tarsi trimerous, total length $0.13 \mathrm{~mm}$; basal tarsomere slightly longer than others; basal and second tarsomere each with small apical spur; pretarsal claw with preapical tooth. Wings: Forewings present only (hind wings absent); forewing elytrous, carapacelike, length $0.60 \mathrm{~mm}$, greatest width $0.31 \mathrm{~mm}$; anterior margin slightly cordate. Surface of wing between veins areolate, with dense, irregular depressions. Venation highly reduced, consisting of: circumambient $\mathrm{C}$, short
$\mathrm{R}$ and $\mathrm{Rs}, \mathrm{MA}$ and $\mathrm{MP}, \mathrm{Cu}$, and very short $\mathrm{A}$ (for proportions see fig. 4a). Stem of R short; stem of $\mathrm{M}$ approximately twice the length. Surface of veins devoid of areolae. Apices of veins barely touching margin of wings. Outer margin of wing with row of minute, evenlyspaced, stiff setulae. Wings meet in straight line for slightly less than half their mesal length; divergent mesally in apical half.

Abdomen: Obscured by forewings and by distortion from compression in holotype. Subgenital plate large, shape of posterior margin typical of family (entire, not bilobed or emarginate).

Type Material: Holotype CNC 642, which is slightly compressed dorsoventrally (especially the head and abdomen). Paratype CNC 644, which displays some details very well (fig. 4b), but those fragments of the body that are preserved are greatly compressed. Forewings of the holotype specimen are fortuitously cleared, which confirmed that the hind wings are indeed absent.

ETYMology: The specific epithet is based on Canada, the country of origin.

Comments: This species appears to be an extinct sister group to Sphaeropsocus and Sphaeropsocopsis, based on the following plesiomorphic features: presence of apical tibial spurs, the palpal segmentation, shape of the anterior margin of the wing, and the long $\mathrm{R}$ and $\mathrm{M}$ stems.

\section{Sphaeropsocites Grimaldi and Engel, new genus}

Type SPecies: Sphaeropsocites lebanensis, new species, in Early Cretaceous Lebanese amber.

DiAgNOSIS: Apomorphically distinguished from all other genera of the family by palpomere $\mathrm{P}_{4}$ swollen; clypeus very large; eyes situated very posteriad on head; each forewing virtually hemispherical in shape (inner margins touching for entire length, not divergent apically); vein $\mathrm{M}$ short and fused to middle of Rs; course of all veins converging towards mesal margin of wing. Plesiomorphically distinguished from all other genera by noncordate shape (lack of humeral arc) on wing base, by fine punctation (vs. areolate surface) on forewing, and less reduced venation: Rs apically branched, crossveins between R-Rs and $\mathrm{M}-\mathrm{Cu}$, incomplete crossvein between $\mathrm{R}$ and $\mathrm{C}$, vein A long, slight claval furrow present. 


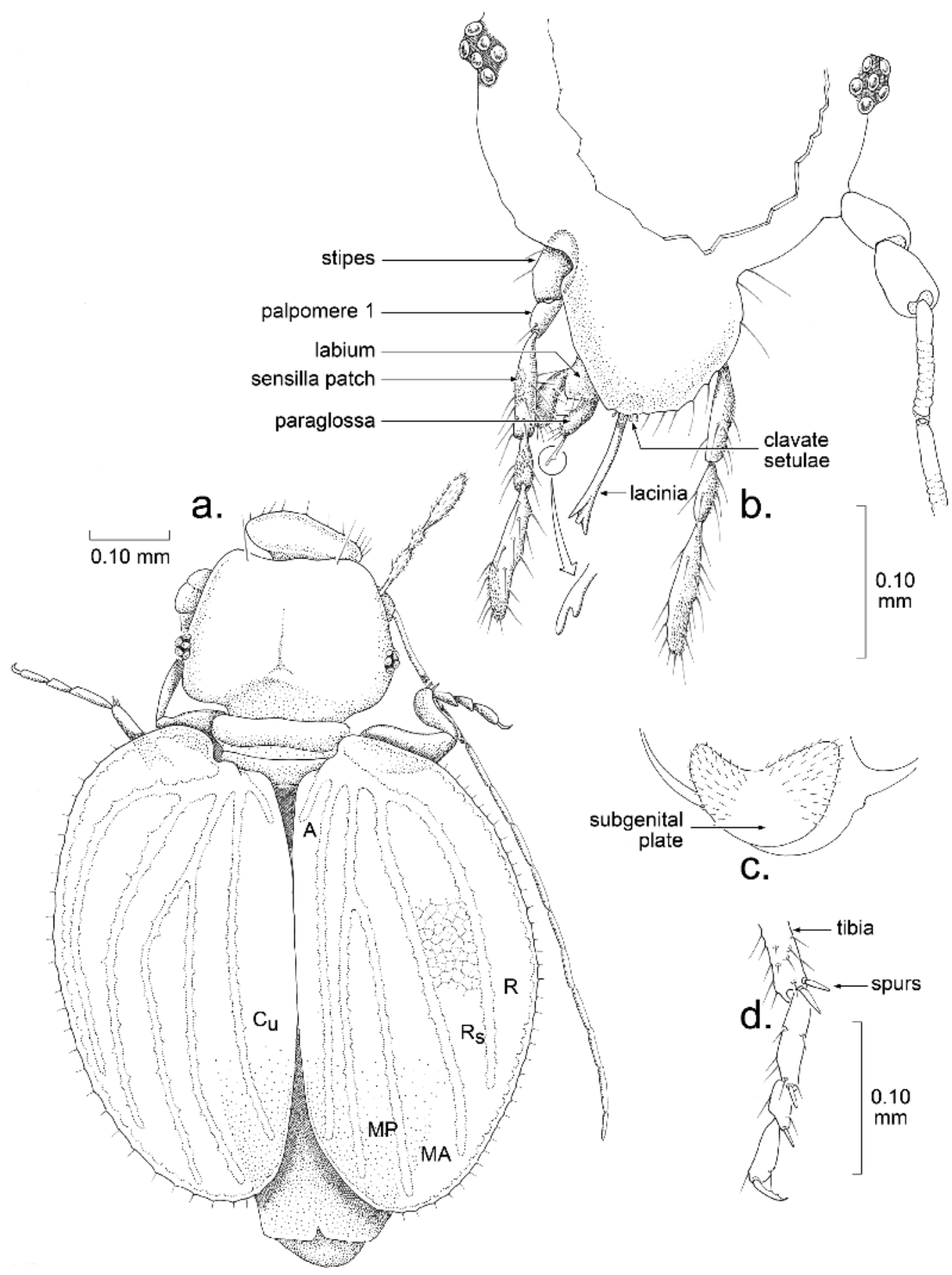

Fig. 5. Sphaeropsocoides canadensis Grimaldi and Engel, new genus and species, in Campanian-aged amber from western Canada. a. Dorsal habitus of holotype, CNC 642. b-d. Details of paratype, CNC 644. b. Anterior portion of head. c. Apical sternites. d. Mesotarsus. 
ETymology: Base of the name is from the type genus of the family, and the suffix -ites is directly from the Greek, meaning "like" or "in the nature of".

Sphaeropsocites lebanensis Grimaldi and Engel, new species Figures 2e, 6

Diagnosis: As for genus (see above).

DESCRIPTION: (Female) (measurements based on unique holotype): Minute psocopteran, body length with forewings $0.83 \mathrm{~mm}$. Head: Prognathous; very broad, width $1.2 \times$ the length. Anterior tentorial pits not apparent (probably not present); median "coronal suture" very short, extended from posterior margin to only level of posterior margin of eyes. Ocelli absent. Compound eyes small, situated very close to posterior margin of head, with six to seven facets not contacting each other. Clypeus large and bulbous; mandibles, labium, lacinia, and base of maxillary palps not visible. Apical palpomere $\left(\mathrm{P}_{4}\right)$ clavate, apical surface with field of dense sensilla. Apex of antenna obscure [total length and number of flagellomeres unknown]; scape and pedicel twice the width of flagellomeres, approximately half the length of basal flagellomere.

Thorax: Short, dorsally with only collarlike pronotum and narrower mesoscutum exposed. Femora and most of forelegs exposed; forelegs of moderate length; femora thick, width of pro- and metafemora $3 \times$ the width of respective tibiae. Lengths of pro- and mesotibiae $0.23 \mathrm{~mm}$; apical tibial spurs apparently absent. Tarsi trimerous, total length $0.17 \mathrm{~mm}$; basal tarsomere much longer than others $(1.5 \times$ the length of tarsomeres $2+3)$; pretarsal claw with preapical tooth. Wings: Forewings present only; (hind wings absent); forewing elytrous, carapacelike, hemispherical in shape, length $0.57 \mathrm{~mm}$, greatest width $0.29 \mathrm{~mm}$; anterior margin not cordate but slightly emarginate. Wings meet mesally in straight line for nearly entire length; divergent only in proximal $1 / 7$ of wing length. Surface of wing between veins with dense, fine areolation or punctation. Venation less reduced than other species of family, consisting of: circumambient $\mathrm{C} ; \mathrm{R} ; \mathrm{Rs}$, to which at midlength is fused a short
$\mathrm{M} ; \mathrm{Cu}$, diverging from stem of $\mathrm{Rs}$ and $\mathrm{M}$, and A (for proportions see fig. 6). Rs apically branched, crossveins present between R-Rs and $\mathrm{M}-\mathrm{Cu}$, an incomplete crossvein between $\mathrm{R}$ and $\mathrm{C}$. Vein A long, slight claval suture present and parallel to A. Surface of veins devoid of areolae. Course of all veins directed towards mesal margin of wing, but not touching wing margin. Outer margin of wing without row of minute, stiff setulae.

Abdomen: Short, globose, approximately same length as forewings but slightly narrower [dorsally obscured by forewings, ventrally by debris].

Holotype: AMNH JS284, collected by Aftim and Fadi Acra from near Jezzine, Lebanon (Early Cretaceous). The piece also contains two male Chironomidae (Diptera). It is dark orange and occluded with fractures, debris, and a network of fine, rootlike plant inclusions. Observation was facilitated by embedding the piece in epoxy, sectioning it, then trimming and grinding close to the insect, but a ventral view of the holotype is still obscured by layers and fractures. Forewings of the holotype are fortuitously cleared, which confirmed that hind wings are indeed absent.

ETYMOLOGY: The specific epithet is a reference to Lebanon, the country of origin for this species.

Comments: Despite the unusual, specialized features of this species, a venation that is least incomplete indicates this species is probably a sister group to all other sphaeropsocids, Recent and extinct.

\section{Key to Genera of Sphaeropsocidae}

1. Forewings separated at midline in apical third or quarter; anal vein absent or reduced to short stub near wing base (fig. 3); crossveins absent

- Forewings meeting at midline for entire length; anal vein distinct and elongate, running along claval suture to near posterior wing margin (fig. 6); crossveins present.

Sphaeropsocites n.gen.

2. Anal vein of forewing present as short stub near wing base ........................................ 3

- Anal vein of forewing completely absent..... 4

3. Humeral angle of forewing distinctly chordate; stem of M greatly shortened. Sphaeropsocus Hagen 


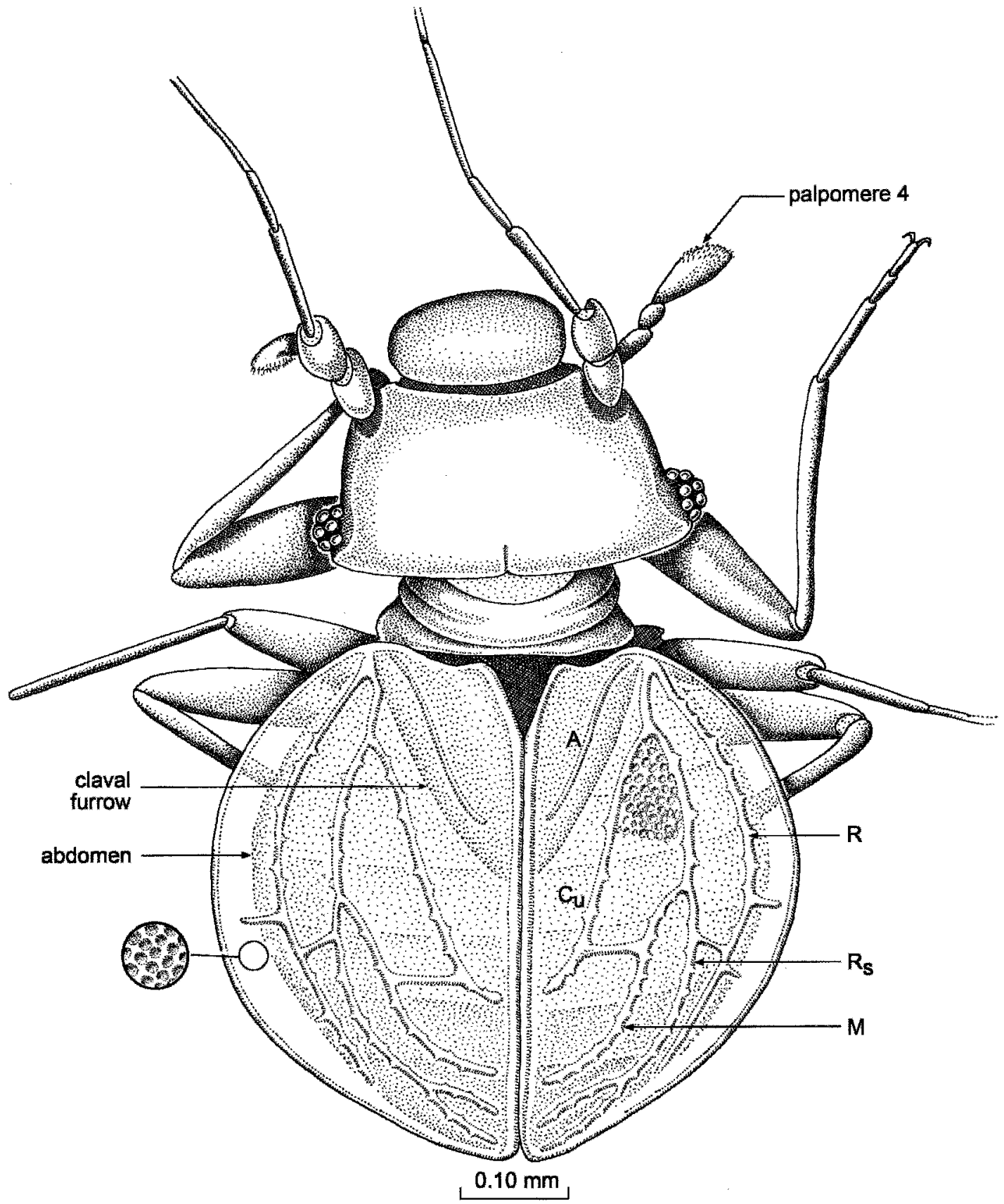

Fig. 6. Sphaeropsocites lebanensis Grimaldi and Engel, new genus and species, in Neocomian-aged amber from Lebanon. Dorsal habitus of holotype AMNH JS-284. 


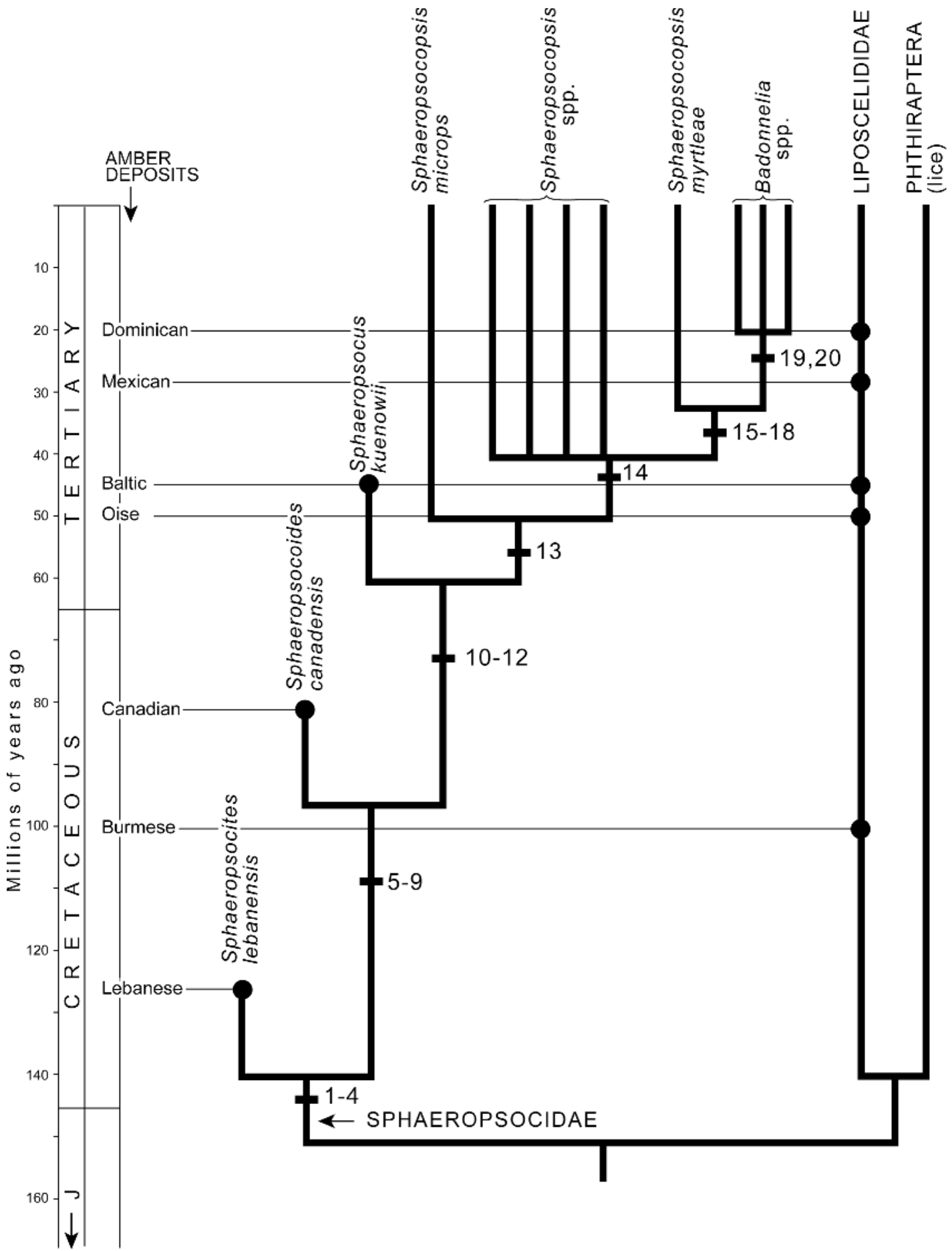

Fig. 7. Cladogram of living and extinct genera. Refer to table 1 for a list of the numbered characters supporting the clades. 
- Humeral angle of forewing present but not enlarged; stem of $\mathrm{M}$ well developed. Sphaeropsocoides n.gen.

4. Forewings with distinct venation, although in brachypterous forms veins are reduced and greatly desclerotized (e.g., Sp. myrtleae); humeral angle chordate, sometimes weakly so........................ Sphaeropsocopsis Badonnel

- Forewing without venation, strongly arched dorsally and extending ventrally on sides to form tear-dropped carapace; humeral angle entirely reduced and tapering gently along wing length

Badonnelia Pearman

\section{RELATIONSHIPS AND BIOGEOGRAPHY}

A preliminary cladogram of sphaeropsocid relationships is provided in figure 7 , based on all fossil and living genera and 16 morphological characters (excluding ones defining the family) (table 1). All characters are entirely consistent with each other (there is apparently no homoplasy), so there was no need for a data matrix and digital analysis. As recently found with the closely related family Liposcelididae (Grimaldi and Engel, 2005b), there is a perfect correlation between the chronology of fossils and the branching sequence of the cladogram.

The oldest fossil of the family, Si. lebanensis in Early Cretaceous amber, branches off first. Despite unusual, autapomorphic features of this species, it possesses an array of features that are plesiomorphic to all other species of the family. These features include a forewing humeral area that is not expanded, wings that meet medially for their entire length, an enlarged vertex, and venation: vein $\mathrm{A}$ is present and is least reduced among all known species, a claval suture is present, and crossveins (three in number) are present. Tibial apices of Si. lebanensis are obscure, but spurs are possibly present. The species that branches off next is $S d$. canadensis in Late Cretaceous Canadian amber. It lacks the large (i.e., cordate-shaped) humeral angle of the more derived species, and it has a pair of small tibial spurs on the apices of at least the fore and mid tibiae. The undescribed sphaeropsocid in midCretaceous amber from Taimyr, Siberia (Rasnitsyn and Quicke, 2002: fig. 164) is still being studied elsewhere, so our comments are based entirely on the published photograph. Like Sphaeropsocus and Sphaeropsocoides in Baltic and Canadian amber (respectively), the
TABLE 1

Characters Used in the Phylogeny of Sphaeropsocidae (see fig. 7)

1. Ommatidia reduced to $0-10$; ocelli lost.

2. Forewings elytrous, sclerotized, carapacelike.

3. Forewing venation reduced, with dense punctation or areolae.

4. Hind wings lost.

5. Vertex of head enlarged.

6. Vein A reduced in size, to usually just a spur.

7. Claval suture lost.

8. All crossveins lost.

9. Humeral area of wing expanded, arched.

10. Tibial spurs lost.

11. Stem of vein $\mathrm{M}$ shortened.

12. Humeral area of wing greatly expanded, cordate in shape.

13. Vein A completely lost.

14. Apices of veins connected and looped near margin of wing.

15. Elytra short, not reaching posterior margin of abdomen.

16. Humeral area of wing greatly reduced.

17. Veins very lightly sclerotized.

18. Venation high reduced, to one or no veins.

19. Venation entirely lost.

20. Lateral surfaces of wings folded against lateral surfaces of abdomen.

Siberian amber specimen appears to lack crossveins, it has incomplete apices of the wing veins, and a fairly short stem to vein $M$. If this is the case, then it would be phylogenetically intermediate between the Baltic and Canadian amber species. Sphaeropsocus kuenowii in Baltic amber is the sister group to living species since it retains an anal vein (albeit a vestigial one). Sphaeropsocopsis microps is perhaps the most primitive Recent species since the apices of the forewing veins are not connected and so do not loop together near the wing margin. In lieu of detailed comparisons among the eight remaining species of the Recent Sphaeropsocopsis, relationships are as yet unresolved but this scheme does include a lineage that consists of the blind, troglobitic species from St. Helena Island, Sp. myrtleae, and Badonnelia. This putative sister-group relationship is based on reduced venation, lightly sclerotized wing veins, and reduction in the wing humeral area. As such, Sphaeropsocopsis appears to be paraphyletic with respect to Badonnelia. Badonnelia is clearly a very specialized and 
monophyletic group since the veins are entirely lost and the lateral parts of the forewings have grown down along the sides of the abdomen.

An understanding of relationships allows better interpretation of the interesting distribution of Sphaeropsocidae. It appears very likely that Recent species of the family are naturally gondwanan, since $S p$. argentina has been introduced to the southern United States from Argentina, and it is quite possible that $B$. titei in Europe and a Sphaeropsocopsis from California were also introduced from Chile or Argentina (Mockford [1993] considered the California specimens to be Sphaeropsocus, but based on the revised definitions by the present authors this species belongs to Sphaeropsocopsis). If this is the case, then most Recent sphaeropsocids are actually austral. The Austral Region includes the temperate regions of southeastern Australia (including Tasmania), New Zealand, New Caledonia and the Fijian Islands, Chile and Argentina, and sometimes southernmost Africa. Taxa with distributions that have an austral disjunction are classically interpreted as relicts of gondwanan drift (Hennig, 1960; Brundin, 1966; summarized in Grimaldi and Engel, 2005a).

Laurasian fossil Sphaeropsocidae would appear to refute an hypothesis that Recent species of the family were affected by gondwanan drift (though Lebanon probably has a gondwanan origin). In fact, the Cretaceous and Eocene fossil sphaeropsocids comprise just stem groups to the Recent species. Extralimital fossils critically depend on the concept of Sphaeropsocidae, which in this case was expanded to include more primitive, extinct species. Grimaldi (1992) established criteria for when fossils can be used to interpret formerly more widespread distributions of Recent lineages, specifically that the fossils must belong to the crown group. Fossil Sphaeropsocidae do clearly establish, though, the possibility that Recent Sphaeropsocidae could have expanded their distribution outside of Recent ones at some time. More importantly, the phylogeny of the family indicates that the Recent genera Sphaeropsocopsis and Badonnelia (fig. 7) are probably entirely Tertiary in age and thus too young to have been affected by Cretaceous tectonics.

\section{ACKNOWLEDGMENTS}

We are grateful to Dr. Edward L. Mockford for information on the undescribed sphaeropsocids collected by him in California in 1953, to Drs. Antonio Arillo and Arturo Baz for reviewing the manuscript, and to Drs. Jeff Cumming, Phil Perkins, and Andrew Ross for the loan of specimens. Partial support for this project was provided by NSF DEB-0542726 (to DG), NSF EF-0341724 (to MSE), and General Research Fund Allocation \#2301360 of the University of Kansas Department of Ecology and Evolutionary Biology (to MSE).

\section{REFERENCES}

Azar, D. 2000. Les Ambres Mésozoïques du Liban. Ph.D. dissertation, University of Paris, Orsay, France, 202 pp.

Badonnel, A. 1951. Ordre des Psocoptères (Psocoptera Psoquillae Latreille, 1810). In P. -P. Grassé (editor), Traité de zoologie: anatomie, systématique, biologie [Tome X: Insectes supérieurs et hémiptéroïdes (Fascicule II)]: 1301-1340. Paris: Masson, 976-1948 pp.

Badonnel, A. 1962. Psocoptères. Biologie de l'Amérique Australe 1: 185-229.

Badonnel, A. 1963. Psocoptères terricoles, lapidicoles et corticicoles du Chili. Biologie de l'Amérique Australe 2: 291-338.

Badonnel, A. 1967. Psocoptères édaphiques du Chile (2e note). Biologie de l'Amérique Australe 3: 541-585.

Badonnel, A. 1971. Sphaeropsocopsis reisi n. sp., premier représentant africain connu de la famille des Sphaeropsocidae (Psocoptera, Nanopsocetae), avec compléments à la faune des Psocoptères angolais. Publicações Culturais da Companhia de Diamantes de Angola 84: 13-28.

Badonnel, A. 1972. Psocoptères édaphiques du Chile (3e note) (Insecta). Bulletin du Muséum National d'Histoire Centrale, Sciences Zoologiques 215: 206-232.

Bekker-Migdisova, E.E., and V.N. Vishniakova. 1962. Order Psocoptera: Booklice (Corrodentia, Copeognatha). In B.B. Rohdendorf (editor), Fundamentals of paleontology [Volume 9: Arthropoda, Tracheata, Chelicerata]: 226-236. Moscow: Akademii Nauk, $561 \mathrm{pp}$.

Broadhead, E. 1950. A revision of the genus Liposcelis Motschulsky with notes on the position of this genus in the order Corrodentia and on the variability of ten 
Liposcelis species. Transactions of the Royal Entomological Society of London 101(10): 335-388.

Brundin, L. 1966. Transantarctic relationships and their significance, as evidenced by chironomid midges with a monograph of the subfamilies Podonominae and Aphroteniinae and the austral Heptagyiae. Kunglica Svenska Vetenskapsakademiens Handlingar 11: 1-472.

Camousseight, A., and T.R. New. 1994. Introducción a los insectos del orden Psocoptera en Chile. Publicación Ocasional del Museo Nacional de Historia Natural, Santiago 49: 5-26.

Carpenter, F.M. 1992. Superclass Hexapoda. In R.L. Kaesler (editor), Treatise on invertebrate paleontology, Part R, Arthropoda: 3-4. Boulder, CO: Geological Society of America, $1-655$.

Enderlein, G. 1911. Die fossilen Copeognathen und ihre Phylogenie. Palæontographica 58: 279-360.

Engel, M.S., and E.E. Perkovsky. 2006a. Sphaeropsocus kuenowii Hagen in Rovno amber from the Ukraine (Psocoptera: Sphaeropsocidae). Entomological News (in press).

Engel, M.S., and E.E. Perkovsky. 2006b. Psocoptera in Eocene Rovno amber from the Ukraine (Insecta). Vestnik Zoologii (in press).

Grimaldi, D.A. 1992. Vicariance biogeography, geographic extinctions, and the North American Oligocene tsetse flies. In M.J. Novacek and Q.D. Wheeler (editors), Extinction and phylogeny: 178-205. New York: Columbia University Press, vi $+[1]+253$ pp.

Grimaldi, D., and M.S. Engel. 2005a. Evolution of the Insects. Cambridge: Cambridge University Press, $\mathrm{xv}+755 \mathrm{pp}$.

Grimaldi, D., and M.S. Engel. 2005b. Fossil Liposcelididae and the lice ages (Insecta: Psocodea). Proceedings of the Royal Society of London, Series B, Biological Sciences 273: 625-633.

Hagen, H.A. 1882. Ueber Psociden in Bernstein. Stettiner Entomologische Zeitung 43: 217-238.

Handlirsch, A. 1907. Die Fossilen Insekten und die Phylogenie der rezenten Formen: Ein Handbuch für Paläontologen und Zoologen. Leipzig: Engelmann, 641-1120 pp.

Hennig, W. 1960. Die Dipteren-Fauna von Neuseeland als Systematisches und Tiergeographisches Problem. Beiträge zur Entomologie 8: 505-688.

Hickman, V.V. 1934. A contribution to the study of Tasmanian Copeognatha. Papers and Proceedings of the Royal Society of Tasmania 1933: 77-89.
International Commission on Zoological Nomenclature. 1999. International Code of Zoological Nomenclature $\left[4^{\text {th }}\right.$ ed.]. London: International Trust for Zoological Nomenclature, xxix + $306 \mathrm{pp}$.

Johnson, K.P., K. Yoshizawa, and V.S. Smith. 2004. Multiple origins of parasitism in lice. Proceedings of the Royal Society of London, Series B, Biological Sciences 271(1550): 1771-1776.

Kolbe, H.J. 1883. Neue Beiträge zur Kenntniss der Psociden der Bernstein-Fauna. Stettiner Entomologische Zeitung 44: 186-191.

Kosmowska-Ceranowicz, B. 1987. Charakterystyka mineralogiczno-petrograficzna bursztynonośnych osadów Eocenu w okolicach ChXpowo oraz osadów Paleogenu Połnocnej Polski. Biuletyn Instytutu Geologicznego 356: 29 50.

Lienhard, C., and N.P. Ashmole. 2000. Sphaeropsocopsis myrtleae sp. n., a blind subterranean psocid from St. Helena (Psocoptera: Sphaeropsocidae). Revue Suisse de Zoologie 106(4): 905-912.

Lienhard, C., and C.N. Smithers. 2002. Psocoptera (Insecta): World catalogue and bibliography. Geneva: Muséum d'Histoire Naturelle, Genève, xli +745 pp.

Lyal, C.H.C. 1985. Phylogeny and classification of the Psocodea, with particular reference to the lice (Psocodea: Phthiraptera). Systematic Entomology 10(2): 145-165.

McAlpine, J.F., and J.E.H. Martin. 1969. Canadian amber: a paleontological treasure-chest. Canadian Entomologist 101(8): 819-838.

Menon, R. 1942. Studies on Indian Copeognatha (Psocoptera), II. Nanopsocetae and Psocatropetae. Indian Journal of Entomology 4(1): 23-42.

Mockford, E.L. 1993. North American Psocoptera (Insecta). Flora and Fauna Handbook 10: xviii $+1-455$.

Nascimbene, P., and H. Silverstein. 2000. The preparation of fragile Cretaceous ambers for conservation and study of organismal inclusions. In D. Grimaldi (editor), Studies on fossils in amber, with particular reference to the Cretaceous of New Jersey: 93-102. Leiden: Backhuys Publishers, viii +498 pp.

O'Connor, J.P. 1987. Badonnelia titei (Psocoptera, Sphaeropsocidae); a splendid addition to the library of the National Museum of Ireland! Entomologist's Monthly Magazine 123(14761479): 125 .

Pearman, J.V. 1936. The taxonomy of the Psocoptera: preliminary sketch. Proceedings of the Royal Entomological Society of London, Series B, Taxonomy 5(3): 58-62. 
Pearman, J.V. 1953. A new generic form allied to Sphaeropsocus Hagen (Psocoptera, Pachytroctidae). Entomologist's Monthly Magazine 89(1073): 262.

Pearman, J.V. 1958. Augmented description of Badonnelia titei Pearman (Psoc., Sphaeropsocidae), with notes on the genus Sphaeropsocus. Entomologist's Monthly Magazine 94(1126): 49-52.

Rasnitsyn, A.P. and D.L.J. Quicke (editors). 2002. History of insects. Dordrecht: Kluwer Academic Publishers.
Ritzkowski, S. 1997. K-Ar-Altersbestimmungen der bersteinführenden Sedimente des Samlandes (Paläogen, Bezirk Kaliningrad). Metalla, Bochum 66: 19-23.

Smithers, C.N. 1972. The classification and phylogeny of the Psocoptera. Memoirs of the Australian Museum 14: 1-349.

Yoshizawa, K., and K.P. Johnson. 2003. Phylogenetic position of Phthiraptera (Insecta: Paraneoptera) and elevated rate of evolution of mitochondrial 12S and 16S rDNA. Molecular Phylogenetics and Evolution 29(1): 102-114. 

Complete lists of all issues of the Novitates and the Bulletin are available at World Wide Web site http://library.amnh.org/pubs. Inquire about ordering printed copies via e-mail from scipubs@amnh.org or via standard mail from: American Museum of Natural History, Library-Scientific Publications, Central Park West at 79th St., New York, NY 10024. TEL: (212) 769-5545. FAX: (212) 769-5009. 